\title{
Research Experiences for Teachers (RET) Site: Sustainable Electronics
}

\section{Dr. Inez Hua, Purdue University}

Dr. Inez Hua is Professor in the Lyles School of Civil Engineering and the Division of Environmental and Ecological Engineering. Her research and teaching areas include aquatic chemistry, water pollution control, environmental sustainability in engineering education, and sustainable electronics. Dr. Hua has a $\mathrm{Ph} . \mathrm{D}$ and an MS in Environmental Engineering and Science from the California Institute of Technology (Caltech), and a BA in Biochemistry from the University of California, Berkeley.

Dr. Monica E Cardella, Purdue University, West Lafayette (College of Engineering)

Monica E. Cardella is the Director of the INSPIRE Institute for Pre-College Engineering Education and is an Associate Professor of Engineering Education at Purdue University.

Dr. Michael L Curry, Tuskegee University 


\section{Research Experiences for Teachers (RET) Site: Sustainable Electronics}

\section{Introduction}

The goal of the three-year Research Experiences for Teachers (RET) Site on Sustainable Electronics is to provide high school STEM teachers, through intensive summer research with faculty at Purdue University-West Lafayette (PU) and Tuskegee University (TU), with the knowledge and skills to equip their students to become part of a technologically adept workforce as well as informed designers and users of sustainable products.

The objectives are: 1) To enhance teacher quality and proficiency in teaching high school science, 2) To increase the number and diversity of students who study STEM (science, technology, engineering and math) in high school and college and choose STEM-related careers and 3) To equip participating teachers to share their knowledge and innovative, science-based curricula within their districts and with a broader, national community of high school STEM teachers.

Our rationale for proposing this project is that there is high demand for a scientifically literate workforce, and substantial societal benefits accrue from a scientifically literate citizenry. In recognition of these demands and benefits, the National Research Council (NRC) set forth three goals for K-12 STEM education [1]: increasing the number of students who earn advanced degrees and choose careers in STEM fields, increasing the "STEM-capable" workforce, and increasing science literacy for all students, regardless of career choice [1]. Broadening the participation of underrepresented groups underpins the first two goals.

Teachers of K-12 STEM play a key role in meeting these goals; thus, teacher preparation and professional development are also greatly needed. A number of studies have demonstrated that student learning benefits from highly qualified teachers [2] and that access to these teachers varies among student demographic groups [3]. Various factors contribute to developing highly qualified teachers, including professional development activities after they have begun their classroom teaching careers. High school (HS) science teachers exhibit a high rate of participation in professional development: In 2012, it was reported that $89 \%$ of those teachers participated in at least one professional development activity in the prior three years [3]. The literature suggests that effective professional development experiences are research-based and use content to increase student learning and development [4].

We have developed and implemented a professional development opportunity that leverages the expertise of engineering scholars at PU and TU_hrough the RET Site: Sustainable Electronics. The research themes links various projects related to sustainable electronics - at both universities. The topic of environmentally sustainable electronics provides both context and application to many scientific and engineering principles. Each research project will be mapped to specific HS science standards, which will guide development of HS curricula. Environmental sustainability as a general context should help broaden female and minority participation in engineering. 


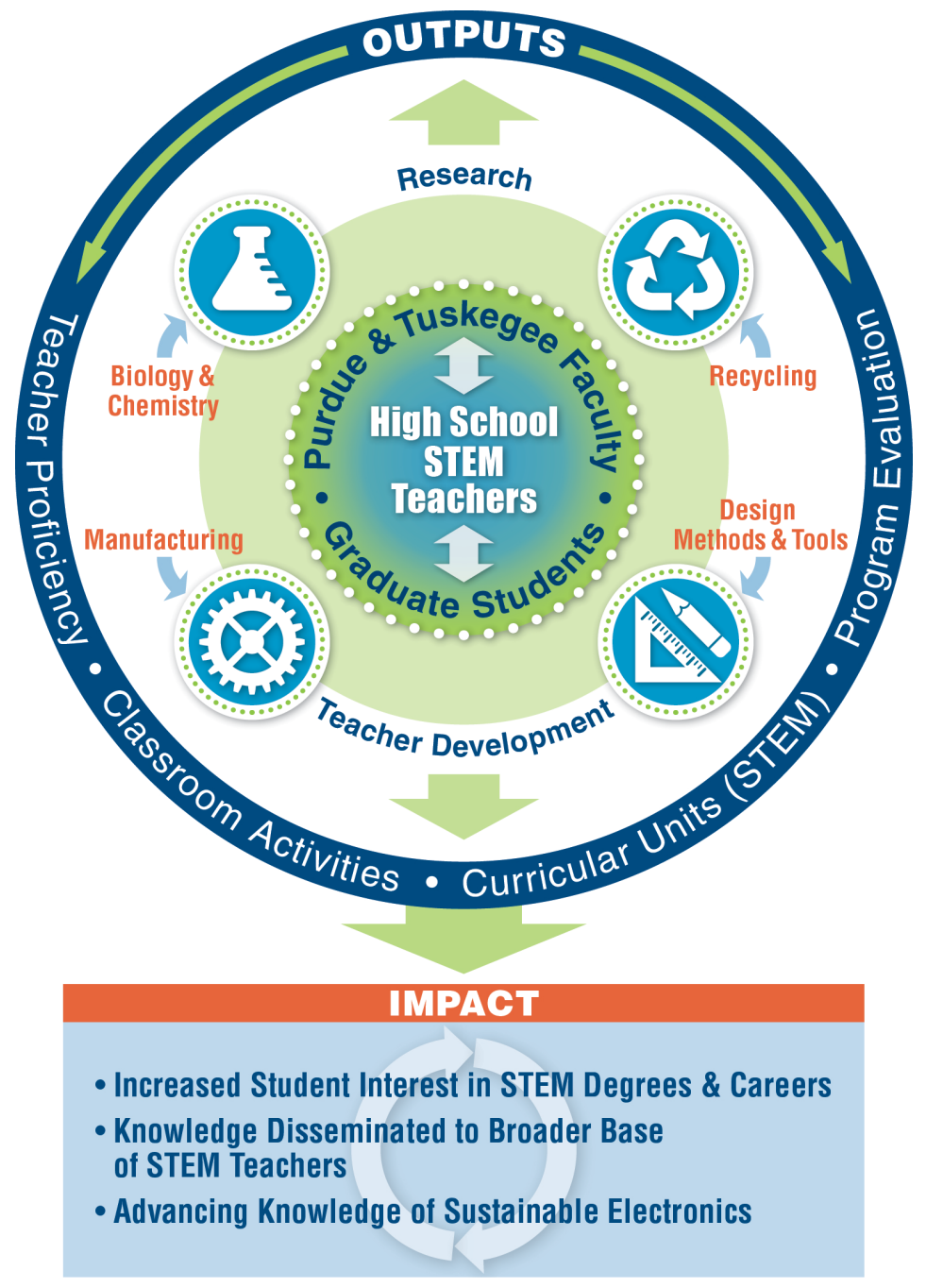

Figure 1. Participants, outcomes and impacts from RET Site: Sustainable Electronics.

In our paper, we present results from a unique professional development opportunity that leverages the expertise of engineering scholars PU and TU through the RET Site: Sustainable Electronics. This program trains 11 high school STEM teachers for six weeks during the summer, and provides an intensive research experience. Complementing the research is a series of other professional development activities to enhance teacher quality, such as field trips and presentations from members of the Industrial Advisory Board. The teachers are provided funding and support to implement new, standard-based curricula into their science courses at their respective high schools. Results from the summer 2016 teacher cohort will be presented, including teacher's research projects' results and the developed high school curricula.

\section{Participant Recruitment, Selection, and Pre-Program Activities}


A comprehensive website was developed and hosted at PU. This website provided information to teachers and an on-line application. Teachers were recruited from school districts in Alabama an Indiana. Recruitment efforts included direct electronic mailings to every district superintendents, targeted visits to specific schools and discussions with potential candidates, as well as mailings to agencies such as the Indiana Department of Education, and professional organizations the Alabama Association of Science Teachers, Inc. In addition, STEM outreach organizations at each university helped promote the program to potential participants. The PIs also posted announcements to social media, including LinkedIN.

Teacher participants were selected based on the quality of a statement of their interest in conducting research and participating in professional development, letters of recommendation from their principals, years of in-service teaching, the demographics of the students that they teach, and the science subject(s) they teach. There were 11 teachers in the first cohort: 4 teachers who participated in the program at TU and 7 teachers who participated at PU.

Once the teachers had been accepted into the program, they were introduced (virtually) to their resesearch advisors, with the intent of having some preliminary discussion about projects ahead of their arrival on campus. These discussions began about six weeks prior to the start of the on-campus summer activities.

\section{Program Description and Teacher Activities Orientation Week}

The initial week provided a thorough theoretical and practical orientation to and overview of the program, including introductions to engineering research as well as expectations of the teachers and mentors. Activities included an overview of the breadth of the research projects and how the research impacts product and process development that results in electronic products. This orientation week also built relationships to create a community across both the teachers and the faculty and graduate student mentors to enhance the learning and experience of the program. This was particularly important, since this RET Site was offered on two campuses in two different states. All teachers convened on the campus of PU for the orientation activities. The teachers than worked at their respective campuses for most of the summer, before reconvening on the campus of PU for the final presentations and program conclusion. The coDirector of the RET Site at PU visited the other campus (TU) for a mid-program review and discussion with teacher participants and other sustainable electronics researchers. Teachers were introduced to research ethics, research methods, research specific training, library resources, and state science standards, among other topics, during the orientation week. Teachers were also introduced to resources on-campus that focus on P-12 STEM learning and outreach. Activities included lectures as well as hands-on activities. For example, a lecture about the circular economy and the life-cycle of electronics included an opportunity for each teacher to dismantling electronics products, analyze the components, and think about the barriers to recyling for electronics products.

\section{Research Experiences and Curriculum Development}

The research experiences at both universities comprised a primary focus of the program.

On a weekly basis, teachers reflected on and shared what they had learned and documented ideas 
for teaching engineering in facilitated conversations. The PU and TU cohorts shared experiences and research results through weekly sessions enabled by WebEx.

Guided reflections explicitly connected the RET experiences with educational standards and applications relevant to students. Each teacher developed a plan for her/his own school and curriculum during this part of the RET. Formative feedback on these plans included weekly feedback from graduate student, research mentors, resource specialists from Engineering Projects in Community Service (EPICS) at PU, and the other teachers in the RET program.

Teachers were also embedded into the research groups of their mentors: they attended goup meetings, discussed research results, and conducted laboratory work, modeling exercises, or other utilized other methodologies to answer their research questions. Teachers also worked with their research group to develop implemenation plans, and in particular, what type of supplies and equipment they would purchase to implement the newly developed curricula.

The research environment and the teacher development were enhanced by interactions with members of the RET Site Industrial Advisory Board (IAB), who provided guidance in terms of research needs for sustainable electronics. Teachers interact edwith these industry partners during the kick-off meeting and during final presentations. Members of the IAB include Tom Okrasinksi, Corporate CTO - Reliability and Environmental Engineering, Alcatel Lucent; Scott O'Connell, Director of Environmental Affairs, Dell Inc.; Lindsey Williams, Vice President, Government Affairs, Delphi Corporation; and Kiley Dove, University Relations Manager, Cisco Systems Limited; and R. V. Joshi, IBM Academy Member and Master Inventor, IBM. During each meeting, IAB members discussed sustainability efforts at their own companies and industry-wide and answered questions from the teachers. In addition, IAB members provided detailed feedback on the research posters at the closing meeting.

Each teacher submitted a final, technical report describing their research results, and also presented a poster to a variety of stakeholders during the final week of the program. Selected research projects and outcomes, science standards, and curricula are included in Table 1. 
Table 1: Selected Teacher Research Projects, Questions, and High School Science Standards

\begin{tabular}{|c|c|c|}
\hline $\begin{array}{l}\text { Research Project } \\
\text { Title }\end{array}$ & Key Research Question & Key HS Science Standard(s) \\
\hline $\begin{array}{l}\text { Tannic Acid, Potential } \\
\text { Flame Retardant? }\end{array}$ & $\begin{array}{l}\text { The research objective focuses on } \\
\text { using tannic acid (TA), found } \\
\text { naturally in plants, as a more } \\
\text { environmentally friendly flame } \\
\text { retardant to improve sustainability } \\
\text { in electronics. }\end{array}$ & $\begin{array}{l}\text { Design, evaluate, and refine a model which shows how human } \\
\text { activities and natural phenomena can change the flow of matter } \\
\text { and energy in an ecosystem and how those changes impact the } \\
\text { environment and biodiversity of populations in ecosystems of } \\
\text { different scales, as well as, how these human impacts can be } \\
\text { reduced. }\end{array}$ \\
\hline $\begin{array}{l}\text { It's All About That } \\
\text { Case: Dopamine } \\
\text { Surface } \\
\text { Functionalization of } \\
\text { Hexagonal Boron } \\
\text { Nitride Particles }\end{array}$ & $\begin{array}{l}\text { Which conditions of hexagonal } \\
\text { boron nitride (hBN) type, } \mathrm{pH}, \\
\text { temperature, time, and dopamine } \\
\text { hydrochloride (DOPA) maximize } \\
\text { the surface modification of hBN? }\end{array}$ & $\begin{array}{l}\text { Differentiate between pure substances and mixtures based on } \\
\text { physical and chemical properties. } \\
\text { Explain that atoms and molecules are in constant motion and that } \\
\text { this motion increases as thermal energy increases. } \\
\text { Distinguish between the concepts of temperature and heat flow in } \\
\text { macroscopic and microscopic terms. } \\
\text { Solve problems involving heat flow, temperature changes, and } \\
\text { phase changes by using known values of specific heat, phase } \\
\text { change constants, or both. } \\
\text { Describe the composition and properties of solutions. } \\
\text { Explain how temperature, pressure and polarity of the solvent } \\
\text { affect the solubility of a solute. }\end{array}$ \\
\hline $\begin{array}{l}\text { Life-Cycle Analysis } \\
\text { of Daily School } \\
\text { Assessments }\end{array}$ & $\begin{array}{l}\text { The research objective is to go } \\
\text { through the raw materials, the } \\
\text { manufacturing, the use, and the } \\
\text { disposal phases of a laptop } \\
\text { computer and the copy paper a } \\
\text { student would need in their high } \\
\text { school career and compare the two } \\
\text { for environmental impact using } \\
\text { Process-based LCA and the } \\
\text { Economic Input Output (EIO)- }\end{array}$ & $\begin{array}{l}\text { Research how human consumption of finite natural resources (i.e. } \\
\text { coal, oil, natural gas, and clean water) and human actvities have } \\
\text { had an impact on the environment (i.e. causes of air, water, soil, } \\
\text { light, and noise pollu;on). } \\
\text { Conduct short research assignments and tasks to answer a ques;on } \\
\text { (including a self- generated ques;on), or test a hypothesis, drawing } \\
\text { on several sources and generating additional related, focused } \\
\text { ques;ons that allow for multiple avenues of exploration. } \\
\text { Identify the criteria and constraints of a design to ensure a } \\
\text { successful solution, taking into account relevant scientific }\end{array}$ \\
\hline
\end{tabular}




\begin{tabular}{|l|l|l|}
\hline & LCA. & $\begin{array}{l}\text { principles and potential impacts on people and the natural } \\
\text { environment that may limit possible solutions. }\end{array}$ \\
\hline $\begin{array}{l}\text { Exploring toxicity of } \\
\text { alternatives to } \\
\text { brominated flame } \\
\text { retardants using } \\
\text { QSAR methods }\end{array}$ & $\begin{array}{l}\text { The purpose of this study is to } \\
\text { determine the impact of } \\
\text { conventional flame retardants and } \\
\text { their replacements on ecosystems } \\
\text { and human health using } \\
\text { computational science. }\end{array}$ & $\begin{array}{l}\text { Analyze cost-benefit ratios of competing solutions for developing, } \\
\text { conserving, managing, recycling and reusing energy and materials } \\
\text { resources to minimize impacts in natural systems. } \\
\text { Construct an explanation based on evidence to determine the } \\
\text { relationships among management of natural resources, human } \\
\text { sustainability, and biodiversity. }\end{array}$ \\
\hline
\end{tabular}




\section{Project Evaluation and Reporting}

Teachers will be interviewed at the beginning and end of the program in order to (1) ensure that we are designing their RET experience in a way that is synergistic with their own learning and development goals, (2) better understand their teaching concerns, and (3) document their teaching approaches.

\section{Teacher Demographics}

Eleven teachers comprised the first cohort: 5 men and 6 women. Nine percent of the teachers were highly experiences (21-25 years of teaching), 45.4\% were experienced (6-15 years), and $45 \%$ were early in their careers ( $<5$ years teaching). All of the participants held bachelors degrees (82\% of those in STEM disciplines) and $45.5 \%$ of participants had earned MS degrees. The teachers taught all grades of high schools science (grades 9-12), and one teacher also taught $8^{\text {th }}$ grade science.

\section{Teacher Development}

Examples of specific skills or conceptual knowledge that the teachers reported gaining during the summer include: research methodology techniques, such as the Jones oxidation methodolog, Quantitative Structure-Activity Relationships (QSAR), and flexure testing; field specific conceptual knowledge such as biodegradability, science of flame retardants, chemical makeup of adhesives, nanotechnology (nanocrystals, nanofibrils, nanotubes), public policy around disposal of electronic waste and recycling, and life cycle assessment. Teachers also reported learning new software, such as "Avogadro," a molecular editor and visualization application.

\section{Curricula Implementation}

Teacher participants had the responsibility of core courses and after-school clubs. PU teachers taught at a range of schools, from schools that are virtual schools to project-based learning (PBL) schools to traditional middle and high schools. TU teachers taught at traditional public high schools. Teaching loads averaged 129 students per teacher, with a range from 44 to 200. Based on teachers' self-reported data, approximately 1,293 students between the states of Indiana and Alabama will receive instruction related to sustainability, chemistry, governmental policy, or environmental impact of electronics disposal. Classroom project plans included field trips, research papers, public symposia, interaction with public officials, and use of classroom equipment purchased with support funding from the program or from a partnership with school science equipment vendors.

In addition, the RET participants at TU have planned a collaboration that approaches a community of practice. The TU teachers have planned combined field trips across their respective schools and districts as well as plan to create two shared curricular modules. The shared modules will be Introduction to Sustainability and Introduction to Research. Each Tuskegee teacher will teach multiple modules from the co-created curriculum and individual 
modules specific to their local teaching assignments. Site-specific modules include Sustainability of Fire Retardants and Sustainability of Natural Jute, and Plastics and Compost. 


\section{References}

1) Successful K-12 STEM Education: Identifying Effective Approaches in Science, Technology, Engineering, and Mathematics. National Research Council (2011).

2) Educating Teachers of Science, Mathematics, and Technology: New Practices for the New Millennium. Committee on Science and Mathematics Teach Preparation. National Research Council (2000).

3) Science and Engineering Indicators 2014. National Science Board. Arlington, VA: National Science Foundation (NSB 14-01)

4) Loucks-Horsley, S., Hewson, P.W., Love, N., and Stiles, K.E. Designing Professional Development For Teachers of Science and Mathematics, Thousand Oaks, CA: Corwin, 1988. 